\title{
Interfacial adaptation and thickness of bioceramic-based root canal sealers
}

\author{
Afaf AL-HADDAD, Noor Hayaty ABU KASIM and Zeti Adura CHE AB AZIZ \\ Department of Restorative Dentistry, Faculty of Dentistry, University of Malaya, 50603 Kuala Lumpur, Malaysia \\ Corresponding authors, 1st:AfafAL-HADDAD; E-mail: afaf_haddad3@yahoo.com,2nd: Zeti Adura CHEAB AZIZ; E-mail: zetiaziz@um.edu.my
}

\begin{abstract}
This study evaluated and compared the sealer thickness and interfacial adaptation of bioceramic sealers (Sankin Apatite III, MTA Fillapex $^{\circledR}$, EndoSequence ${ }^{\circledR}$ BC) to root dentin against AH Plus ${ }^{\circledR}$ sealer. Sixty extracted single-root premolars were prepared and equally divided into four groups. Sealers were labeled with $0.1 \%$ Rhodamine B fluorescent dye. Roots were dissected along the transverse plane at $1 \mathrm{~mm}$ (apical), $3 \mathrm{~mm}$ (middle), and $6 \mathrm{~mm}$ (coronal) levels. Sealer-to-whole canal area ratio was evaluated. Percentage of gap-containing region to canal circumference was calculated using a confocal laser microscope. Sealer thickness was significantly higher at apical and middle levels than at coronal level. EndoSequence BC had the significantly highest thickness compared with MTA Fillapex and AH Plus. The coronal level had significantly less interfacial gaps compared with apical and middle levels. Bioceramic sealers showed more gaps compared with AH Plus, with no significant differences among them.
\end{abstract}

Keywords: Bioceramic root sealer, Confocal laser analysis, Interfacial adaptation, Sealer thickness

\section{INTRODUCTION}

The aim of root canal filling is to prevent reinfection of the canal by providing adequate seal against ingress of bacteria and their toxins ${ }^{1)}$. Gutta-percha (GP) is used in combination with root sealers to achieve this objective ${ }^{2}$. Sealers seal off voids, patent accessory canals and multiple foramina, form a bond between GP and root canal dentin, and entomb the remaining bacteria ${ }^{3}$. Therefore, sealers play an essential role in the success of root canal treatments ${ }^{4}$. The efficacy of root sealers is enhanced by minimizing the amount of sealer used and ensuring good adaptation and penetration of the sealer into root dentin ${ }^{5,6)}$. The increased efficacy of root sealers stems from an increase in contact surface area between dentin and the sealer, thereby increasing antibacterial action at sealer-dentin interface ${ }^{6,7)}$. However, sealer thickness $^{8)}$ and adaptation to root dentin ${ }^{9)}$ is largely a function of the sealer's physical and chemical properties.

Sealers can be categorized based on their main components: zinc oxide-eugenol, calcium hydroxide, glass ionomer, silicone, resin, or bioceramic-based root canal sealers. Bioceramics are materials specifically designed for medical and dental applications. Bioceramic materials include alumina, zirconia, bioactive glass, glass ceramics, hydroxyapatite, and calcium phosphates ${ }^{10)}$. Dentin interacts with bioceramic-based root sealers, especially calcium silicate-based root sealers, via the chemical uptake of calcium and silicon in the presence of a phosphate buffer solution ${ }^{11)}$. This interfacial interaction, known as "mineral infiltration zone", is triggered by the alkaline caustic effects of the sealer's by-products and involves the penetration of sealer minerals (carbonate, calcium, and silica) into intertubular dentin after the denaturation of collagen fibers ${ }^{12)}$.

Sankin Apatite (Sankin-kogyo, Tokyo, Japan) is a bioceramic sealer. Its powder component comprises alpha-tricalcium phosphate and hydroxyapatite, and its liquid component contains polyacrylic acid which exhibits some degree of cytotoxicity ${ }^{13)}$. Its sealing ability was comparable to Grossman sealer ${ }^{14)}$ but lower than that of AH Plus ${ }^{15)}$.

Launched in 2009, EndoSequence ${ }^{\circledR}$ BC (Brasseler, Savannah, USA) - also known as iRoot $\mathrm{SP}^{\circledR}$ (Innovative Bioceramix, Vancouver, Canada) — is a new bioceramic root canal sealer. According to its manufacturer, EndoSequence BC is an insoluble, aluminum-free, radiopaque material. It is composed of calcium silicate, calcium phosphate, calcium hydroxide, and zirconium oxide. Unlike other bioceramic root canal sealers, EndoSequence BC requires the presence of water to set and harden.

MTA Fillapex $^{\circledR}$ (Angelus, Londrina, PR, Brazil) is a new MTA-based sealer. The major constituents of MTA are tricalcium silicate, dicalcium silicate, tricalcium aluminate, and tetracalcium aluminoferrite silicate ${ }^{16)}$. MTA Fillapex is considered a combined bioceramic resin sealer due to the addition of salicylate resin ${ }^{17}$.

Both EndoSequence BC and MTA Fillapex exhibit good physical properties ${ }^{17,18}$. The sealing ability of iRoot SP was comparable to AH Plus ${ }^{\circledR}{ }^{19)}$, whereas MTA Fillapex exhibited higher leakage than $\mathrm{AH}$ Plus ${ }^{20)}$. Both sealers bonded strongly to root dentin ${ }^{21)}$. However, there is a paucity of information regarding the thickness and interfacial adaptation to root dentin of these sealers. Therefore, this study aimed to evaluate the thickness and interfacial adaptation of three bioceramic-based sealers in comparison with the epoxy resin-based $\mathrm{AH}$ Plus sealer.

\section{MATERIALS AND METHODS}

\section{Specimen preparation}

Sixty extracted human single-root premolars were selected after being radiographed buccolingually and 
mesiodistally. Inclusion criteria were as follows: single straight root canal, completely formed apex with patent foramina, no obstruction within canal system, and no evidence of internal and/or external resorption. Selected teeth were decoronated at $16 \mathrm{~mm}$ from the apex to standardize the length of all specimens. After pulp extirpation, size $10 \mathrm{~K}$-file (Dentsply Maillefer) was introduced into the canal until it was visible at the apical foramen. True working length was established by subtracting $1.0 \mathrm{~mm}$ from this measurement.

Root canal preparation was carried out using a modified step-down technique ${ }^{22)}$. Coronal two-third was flared using Gates-Glidden drills sizes 4, 3, and 2 (Dentsply Maillefer). Apical third was prepared using K-files up to master apical file size 35, followed by stepback in 1-mm increments up to file size 60. Canals were irrigated between each file change with $3 \mathrm{~mL}$ of $5.25 \%$ $\mathrm{NaOCl}$ (Clorox (M) Industries, Malaysia). Final irrigation was done using $5 \mathrm{~mL}$ of $17 \%$ EDTA (SmearClear ${ }^{\mathrm{TM}}$, SybronEndo, Orange, CA, USA) for 3 min to eliminate the smear layer, followed by irrigation with $5 \mathrm{~mL}$ of distilled water and drying with paper points (Dentsply Maillefer).

\section{Obturation}

Specimens were randomly divided into four groups according to the type of sealer used (Table 1). Roots were obturated using cold lateral compaction technique. A size 35 GP master cone (ISO color coded, Dentsply Maillefer) was placed in each canal with tug-back at the working length. All sealers were prepared according to their manufacturers' instructions. Each sealer was labeled using 0.1\% Rhodamine B dye (SigmaAldrich, St. Louis, MO, USA) ${ }^{23}$. A dye-sealer mixture (approximately $0.05 \mathrm{~mL}$ ) was applied along the entire length of each canal using paper points. GP master cone was lightly coated with sealer and inserted into the canal. Root canals were filled with fine-sized accessory gutta-percha points (Dentsply Maillefer) laterally compacted with a fine-sized finger spreader (Dentsply
Maillefer) inserted $2 \mathrm{~mm}$ short of the working length. Compaction continued until the spreader could not be inserted more than $2 \mathrm{~mm}$ into the canal.

GP cones were seared off at canal orifice. Radiographs were taken at buccal and mesial aspects to assess the quality of root canal filling. Filling was considered satisfactory if it appeared to be dense without voids and extended within $1 \mathrm{~mm}$ from the root end. Access was restored with IRM (Dentsply International, Caulk, Milford, DE, USA). All specimens were kept in an incubator at $37^{\circ} \mathrm{C}$ in $100 \%$ humidity for 10 days to allow sealers to set. Each root was mounted using an epoxy resin (Mirapox, Miracon, Malaysia) and sectioned transversely at $1 \mathrm{~mm}$ (apical), $3 \mathrm{~mm}$ (middle), and $6 \mathrm{~mm}$ (coronal) from the terminus of the filling using a low-speed saw (Micracut 125 Low Speed Precision Cutter, Metkon) with copious coolant irrigation.

\section{Stereomicroscope analysis}

Any GP smear found on each sectioned surface was removed using a carbon steel surgical scalpel blade (No. 15, Braun, Aesculap, Germany) with shaving movement. Specimens were mounted on glass slides, and only the coronal facing surface was examined. Each section was examined under a stereomicroscope (SZX7, Olympus, Japan) at $\times 50$ magnification, and the image was captured and transferred to an image analysis software $\left(\mathrm{Cell}^{\wedge} \mathrm{D}\right.$, version $2.4 .112-240608$, Olympus). Area of the entire root canal and that of sealer were outlined and measured. Sealer thickness was calculated as the percentage of sealer occupying the cross-section.

\section{Confocal laser analysis}

For further evaluation, each cross-section was examined under confocal laser scanning microscopy (CLSM, LAS TCS SP5 II, Leica, Mannheim, Germany). Images at $\times 100$ magnification were recorded using the fluorescent mode with laser emission wavelengths at 546-674 nm and excitation at $543 \mathrm{~nm}$. Sealer-dentin interfaces were

Table 1 Components and manufacturers of sealers used

\begin{tabular}{|c|c|c|}
\hline Sealer name & Manufacturere & Components \\
\hline $\begin{array}{l}\text { EndoSequence } \\
\text { BC Sealer }\end{array}$ & $\begin{array}{l}\text { Brasseler USA, } \\
\text { Savannah, GA }\end{array}$ & $\begin{array}{l}\text { Zirconium Oxide, Calcium Silicates, Calcium Phosphate, } \\
\text { Calcium Hydroxide, filler and thickening agents }\end{array}$ \\
\hline MTA-Fillapex & $\begin{array}{l}\text { Angelus, Londrina, } \\
\text { PR, Brazil }\end{array}$ & $\begin{array}{l}\text { Salicylate resin, diluting resin, natural resin, bismuth trioxide, } \\
\text { nanoparticulated silica, MTA (tricalcium silicate, dicalcium silicate, } \\
\text { tricalcium aluminate, and tetracalciumaluminoferritesilicate), pigments }\end{array}$ \\
\hline $\begin{array}{l}\text { Sankin Apatite Root } \\
\text { Canal Sealer (III) }\end{array}$ & $\begin{array}{l}\text { Sankin-kogyo, } \\
\text { Tokyo, Japan }\end{array}$ & $\begin{array}{c}\text { Powder: Alpha-tricalcium phosphate and hydroxyapatite in type I, } \\
\text { iodoform added to powder in type II (30\%) and Type III 5\% } \\
\text { Liquid: Polyacrylic acid and water }\end{array}$ \\
\hline AH Plus & $\begin{array}{l}\text { Dentsply De Trey, } \\
\text { Konstanz, Germany }\end{array}$ & $\begin{array}{l}\text { Paste A: Bisphenol-A epoxy resin, Bisphenol-F epoxy resin, } \\
\text { Calcium tungstate, Zirconium oxide, Silica and Iron oxide pigments } \\
\text { Paste B: enzyldiamine, Aminoadamantane, Tricyclodecane-diamine, } \\
\text { Calcium tungstate, Zirconium oxide, Silica and Silicone oil }\end{array}$ \\
\hline
\end{tabular}


evaluated, and interfacial integrity was determined by calculating the percentage of gap-containing region to the circumference of whole root canal section.

\section{Statistical analysis}

ANOVA repeated measures test was used to analyze the variance among root canal levels and among the different types of sealers. Significant value was set at $p=0.05$.

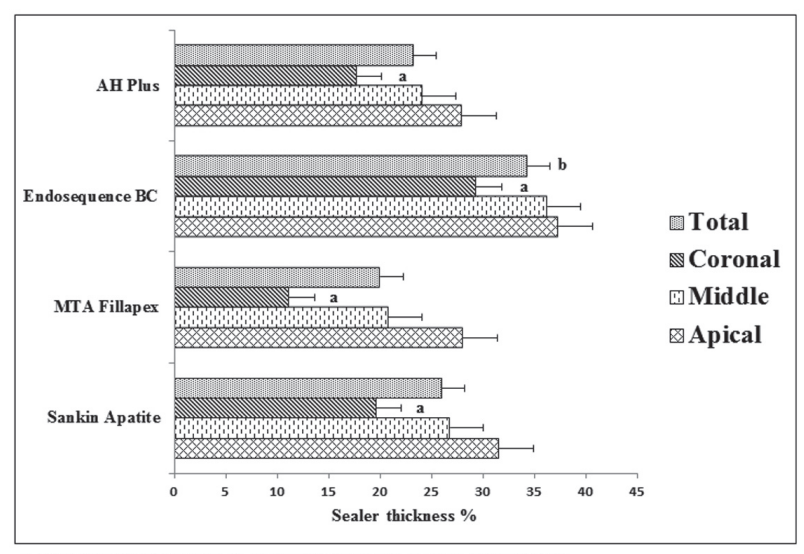

a Significant difference in sealer thickness between canal levels b Significant difference in sealer thickness between different sealers

Fig. 1 Mean values of sealer thickness for different types of sealers.

\section{RESULTS}

Mean sealer thickness values are shown in Fig. 1. There were significant differences among the three levels of root canal: $\mathrm{F}(1.9,105.43)=21.198$. Sealer thickness at each level was not influenced by the type of sealer. Bonferroni pairwise comparison test showed that the coronal level had significantly lower thickness than apical and middle thirds $(p<0.001)$. Comparison among

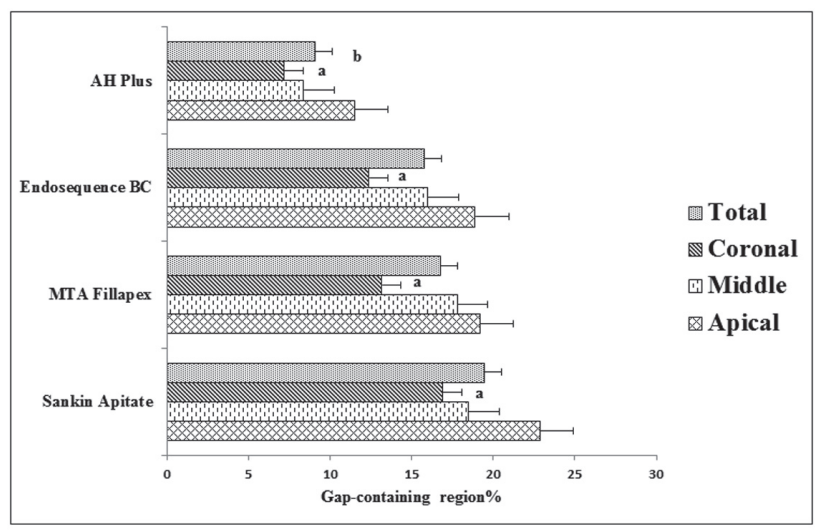

a Significant difference in gap-containing region between canal levels b Significant difference in gap-containing region between different sealers

Fig. 2 Mean values of interfacial adaptation for different types of sealers.
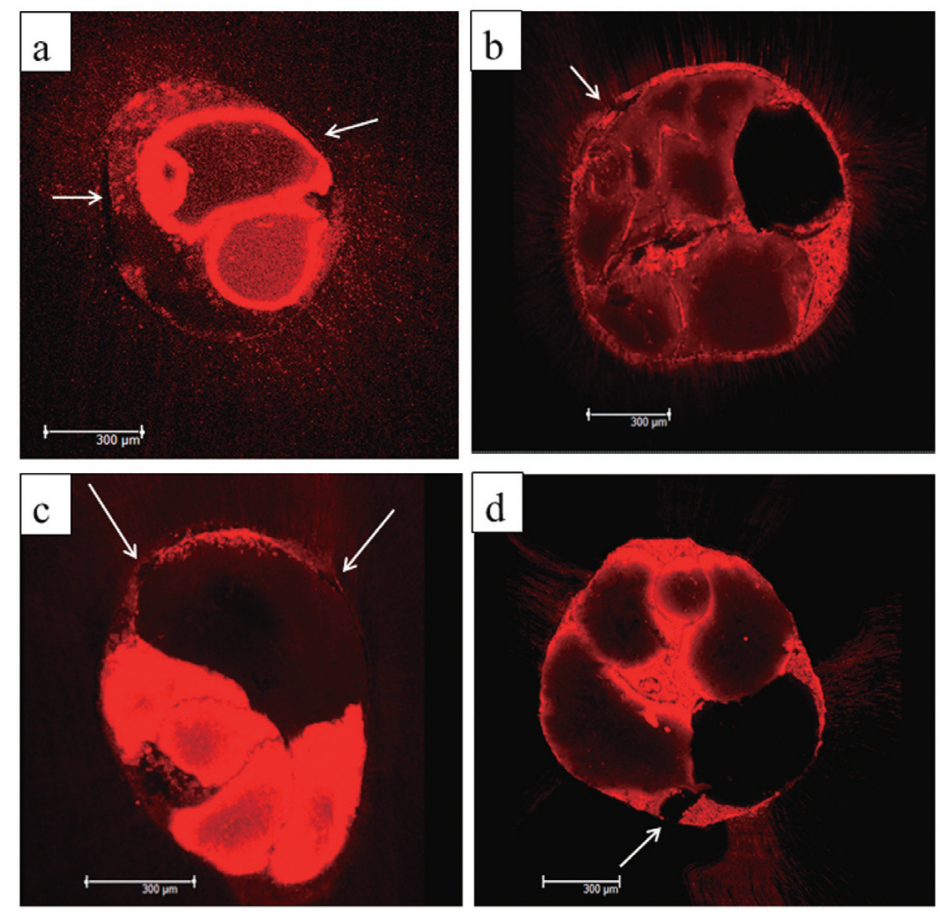

Fig. 3 Representative subsurface confocal images of gap-containing regions (arrow) in different sealers used. (a) Sankin Apatite; (b) MTA Fillapex; (c) EndoSequence BC; and (d) AH Plus. Gap formation was accompanied by penetration of sealer into dentinal tubules, as observed in (a), (b), and (c). No tubular penetration of sealer is observed for gap region with AH Plus (d). 
the types of sealers also revealed highly significant differences. Bonferroni multiple comparison test showed significant differences between EndoSequence BC and both MTA Fillapex $(p<0.001)$ and AH Plus $(p=0.005)$. However, no significant difference was observed between EndoSequence BC and Sankin Apatite. Similarly, no significant differences were detected among Sankin Apatite, MTA Fillapex, and AH Plus.

Mean percentages of gap-containing region are shown in Fig. 2. There were highly significant differences among the three levels of root canal: $\mathrm{F}(1.8$, 101.75)=11.17. Bonferroni pairwise comparisons showed that the coronal level had significantly lower gapcontaining region than the apical $(p<0.001)$ and middle levels $(p=0.022)$. However, no significant differences were observed between the apical and middle levels. Comparison among the different types of sealers revealed statistically significant differences: $F(3$, $56)=17.83$. Bonferroni multiple comparison test showed significant differences between the bioceramic sealers and $\mathrm{AH}$ Plus. However, there were no significant differences among the bioceramic sealers. Figure 3 shows the gap-containing regions of all sealers.

\section{DISCUSSION}

EndoSequence BC is chemically similar to MTA Fillapex, with the exception that EndoSequence BC also contains calcium phosphate. Therefore, MTA Fillapex was used in this study as an MTA-based sealer, while Sankin Apatite III served as the calcium phosphate-based sealer. The aim was to evaluate the effects of different components from within the same bioceramic category on thickness and adaptation of sealers to root dentin. Epoxy resin-based AH Plus was used as the control as it has been considered the benchmark root sealer against which most other sealers were compared.

Sealer thickness is one of the variables evaluated in this study because of the tendency of sealers to shrink and dissolve over time. Low sealer thickness is preferred over high thickness as low thickness enhances the longterm sealing ability of root filling materials ${ }^{8}$. De-Deus $e t$ $a l$. evaluated the sealing ability of Pulp Canal Sealer ${ }^{\mathrm{TM}}$, EndoREZ $^{\circledR}$, Sealapex ${ }^{\mathrm{TM}}$, and AH Plus at two different thicknesses using a microbial leakage test ${ }^{24}$. They reported that the sealing ability of a sealer was inversely proportional to its thickness ${ }^{24}$. However, this finding was not applicable to AH Plus, and this was due to increased antibacterial activity and reduced volumetric shrinkage associated with high thickness for $\mathrm{AH} \mathrm{Plus}^{24)}$.

In this study, EndoSequence BC sealer had significantly higher thickness than AH Plus and MTA Fillapex. The high thickness of EndoSequence BC sealer might be a result of its high calcium silicate content which does not shrink during setting and which hardens in the presence of water ${ }^{19}$. MTA Fillapex produced a significantly lower thickness than EndoSequence BC, and this could be attributed to the differences in their compositions. EndoSequence BC was a bioceramic-based sealer and MTA Fillapex a combined resin-bioceramic sealer ${ }^{17)}$. Like AH Plus, the higher thickness of EndoSequence BC positively affected its sealing ability. It was previously reported that a hermetic seal was formed inside the root canal when single cone technique was used with EndoSequence BC ${ }^{19}$.

Different methods have been used to assess sealer thickness: grid system ${ }^{8}$, linear measurement to the area with higher film thickness ${ }^{25)}$, and quantification of area percentage occupied by sealer ${ }^{26)}$. In the current study, percentage of area occupied by sealer was used as it is reliable and applicable.

Adhesion of root canal sealer to root dentin is a basic requirement of any root filling material ${ }^{27}$. Degree of adhesion depends on a multitude of interacting factors, including the adherent's (dentin) intermolecular surface energy and cleanliness, and the adhesive's (sealer) surface tension and wetting ability ${ }^{28}$. Clinically, the critical root filling area that is susceptible to bacterial leakage is located at the sealer-dentin interface ${ }^{299}$.

In this study, more gaps were observed at the apical level of all sealer types than at the coronal level. This observation was consistent with those of other studies $^{30,31)}$. The discrepancy between the apical and coronal levels might be accounted for by the lower density and diameter of dentinal tubules found at the apical level, resulting in lower sealer penetration ${ }^{32}$. Moreover, difficulty in removing the smear layer at the apical third might act as a physical barrier which interfered with sealer adaptation to root canal dentin ${ }^{33)}$. Higher gap percentage at the middle level could be attributed to the difficulty posed by the oval shape of premolar root canals. Published literature had indicated that this area could prove challenging during preparation and subsequent filling, especially with cold lateral compaction ${ }^{4}$.

AH Plus sealer exhibited the least number of gapcontaining regions, a finding consistent with previous studies $^{34,35}$. The superior adaptation of AH Plus could be due to its ability to bond to root dentin chemically by reacting with any exposed amino groups in collagen to form covalent bonds between the epoxy resin and collagen $^{28)}$. Unlike alkaline bioceramic-based sealers ${ }^{36)}$, AH Plus is slightly acidic and might result in selfetching when in contact with dentin, thereby enhancing interfacial bonding and adaptation ${ }^{37)}$. Furthermore, the alkaline nature of many bioceramic by-products has been reported to denature dentinal collagen fibers, which then facilitated the penetration of sealers into the dentinal tubules ${ }^{12)}$. However, we observed the presence of gaps despite sealer penetration into the dentinal tubules (Fig. 3). A similar phenomenon was reported for self-adhesive sealers due to polymerization shrinkage during setting ${ }^{34)}$. MTA Fillapex and Sankin Apatite III contain polymers susceptible to polymerization shrinkage. Moreover, despite the manufacturer of EndoSequence BC claiming that the product contains no polymers, independent researchers had identified the presence of carbon polymer which had not been previously reported by the manufacturer ${ }^{36}$.

EDTA (17\%) was used as an irrigant in this study, as it had been demonstrated to decrease the wetting ability 
of dentinal walls ${ }^{37}$, thereby producing an environment suitable for the adhesion of hydrophobic materials such as AH Plus. Therefore, the hydrophobicity of AH Plus sealer facilitated the permeation of resin into the open dentinal tubules and created efficient micro-retention ${ }^{38)}$. However, the decreased wetting ability of the dentin surface prohibited the adhesion of any hydrophilic materials ${ }^{39)}$. Bioceramic-based sealers are hydrophilic by nature, such that their setting and adhesion abilities were a function of the humidity of the root canal ${ }^{40)}$. In the current study, although distilled water was used for the final irrigation, it might have been insufficient to completely flush away EDTA and increase the wetting ability of dentin.

Sankin Apatite III showed a higher number of gaps compared with AH Plus. Similar findings have been reported in the literature ${ }^{15)}$. Yang et al. reported that Sankin Apatite III failed to penetrate nearly all the dentinal tubules and was readily detached from the dentin surface ${ }^{15)}$. Interfacial gaps are clinically problematic as they could result in bacterial leakage and subsequent root canal reinfection. However, the antibacterial properties of EndoSequence BC and MTA Fillapex $^{41,42)}$ might be able to compensate for their reduced adaptation by eradicating the infection that invades the canal through microleakage ${ }^{43)}$. Sankin Apatite type I, however, does not have any antibacterial properties on its own ${ }^{44)}$. With the addition of $5 \%$ iodoform, Sankin Apatite Type III might exert some antibacterial activity. Further investigation is necessary to evaluate the antibacterial properties of both Sankin Apatite types II and III.

Another plausible explanation for the observed high thickness and presence of interfacial gaps concerns the cold lateral compaction technique used. Lateral compaction technique was used in the current study because it is the most commonly taught and practiced technique. It also has advantages of controlled placement of root filling cores into the root canal, greater patient comfort ${ }^{45)}$, and successful employment by large numbers of dentists and students ${ }^{46)}$. The use of lateral compaction technique has been reported to produce high sealer thickness and more voids ${ }^{8)}$. It has also been shown to produce non-homogeneous sealer layers along the entire root canal wall ${ }^{47,48)}$, subsequently influencing the percentage of sealer penetration into root canal dentin ${ }^{23)}$. An alternative obturation technique could have led to different results.

\section{CONCLUSION}

Within the limitations of this study, bioceramic-based sealers exhibited more gap-containing regions when compared with AH Plus, and EndoSequence BC sealer produced the highest sealer thickness.

\section{ACKNOWLEDGMENTS}

This study was supported by UMRG grant (No: RG407/12HTM), University of Malaya, Malaysia.

\section{REFERENCES}

1) Epley SR, Fleischman J, Hartwell G, Cicalese C. Completeness of root canal obturations: Epiphany techniques versus guttapercha techniques. J Endod 2006; 32: 541-544.

2) Michaud RA, Burgess J, Barfield RD, Cakir D, McNeal SF, Eleazer PD. Volumetric expansion of gutta-percha in contact with eugenol. J Endod 2008; 34: 1528-1532.

3) Ørstavik D. Materials used for root canal obturation: technical, biological and clinical testing. Endod Topics 2005; 12: $25-38$

4) Wu MK, Kašt'áková A, Wesselink PR. Quality of cold and warm gutta-percha fillings in oval canals in mandibular premolars. Int Endod J 2001; 34: 485-491.

5) Wu MK, Wesselink PR, Boersma J. A 1-year follow-up study on leakage of four root canal sealers at different thicknesses. Int Endod J 1995; 28: 185-189.

6) Wu MK, de Gee AJ, Wesselink PR. Effect of tubule orientation in the cavity wall on the seal of dental filling materials: an in vitro study. Int Endod J 1998; 31: 326-332.

7) Heling I, Chandler NP. The antimicrobial effect within dentinal tubules of four root canal sealers. J Endod 1996; 22: 257-259.

8) Weis MV, Parashos P, Messer HH. Effect of obturation technique on sealer cement thickness and dentinal tubule penetration. Int Endod J 2004; 37: 653-663.

9) Okşan T, Aktener BO, Şen BH, Tezel H. The penetration of root canal sealers into dentinai tubules. A scanning electron microscopic study. Int Endod J 1993; 26: 301-305.

10) Hench LL. Bioceramics: From concept to clinic. J Am Ceram Soc 1991; 74: 1487-1510.

11) Han L, Okiji T. Uptake of calcium and silicon released from calcium silicate-based endodontic materials into root canal dentine. Int Endod J 2011; 44: 1081-1087.

12) Atmeh AR, Chong EZ, Richard G, Festy F, Watson TF, Dentin-cement interfacial interaction: calcium silicates and polyalkenoates. J Dent Res 2012; 91:454-459.

13) Kim JS, Baek SH, Bae KS. In vivo study on the biocompatibility of newly developed calcium phosphate-based root canal sealers. J Endod 2004; 30: 708-711.

14) Bilginer S, Esener T, Soylemezoglu F, Tiftik AM. The investigation of biocompatibility and apical microleakage of tricalcium phosphate based root canal sealers. J Endod 1997; 23: 105-109.

15) Yang SE, Baek $\mathrm{SH}$, Lee $\mathrm{W}$, Kum KY, Bae KS. In vitro evaluation of the sealing ability of newly developed calcium phosphate-based root canal sealer. J Endod 2007; 33: 978981.

16) Torabinejad M, Hong CU, McDonald F, Pitt Ford TR. Physical and chemical properties of a new root-end filling material. J Endod 1995; 21: 349-353.

17) Zhou HM, Shen Y, Zheng W, Li L, Zheng YF, Haapasalo M. Physical properties of 5 root canal sealers. J Endod 2013; 39: 1281-1286.

18) Vitti RP, Prati C, Silva EJ, Sinhoreti MA, Zanchi CH, de Souza e Silva MG, Ogliari FA, Piva E, Gandolfi MG. Physical properties of MTA Fillapex sealer. J Endod 2013; 39: 915918.

19) Zhang W, Li Z, Peng B. Assessment of a new root canal sealer's apical sealing ability. Oral Surg Oral Med Oral Pathol Oral Radiol Endod 2009; 107: e79-e82.

20) Sonmez IS, Oba AA, Sonmez D, Almaz ME. In vitro evaluation of apical microleakage of a new MTA-based sealer. Eur Arch Paediatr Dent 2012; 13: 252-255.

21) Nagas E, Uyanik MO, Eymirli A, Cehreli ZC, Vallittu PK, Lassila LV, Durmaz V. Dentin moisture conditions affect the adhesion of root canal sealers. J Endod 2012; 38: 240-244.

22) Goerig AC, Michelich RJ, Schultz HH. Instrumentation of root canals in molar using the step-down technique. J Endod 
1982; 8: 550-554.

23) Ordinola-Zapata R, Bramante CM, Bernardineli N, Graeff MS, Garcia RB, de Moraes IG, Debelian G. A preliminary study of the percentage of sealer penetration in roots obturated with the Thermafil and RealSeal-1 obturation techniques in mesial root canals of mandibular molars. Oral Surg Oral Med Oral Pathol Oral Radiol Endod 2009; 108: 961-968.

24) De-Deus G, Coutinho-Filho T, Reis C, Murad C, Paciornik S. Polymicrobial leakage of four root canal sealers at two different thicknesses. J Endod 2006; 32: 998-1001.

25) de Deus GA, Martins F, Lima AC, Gurgel-Filho ED, Maniglia $\mathrm{CF}$, Coutinho-Filho T. Analysis of the film thickness of a root canal sealer following three obturation techniques. Pesquisa Odontológica Brasileira 2003; 17: 119-125.

26) Garcia Lda F, Consani S, Pires-de-Souza Fde C, de Almeida GL. In vitro analysis of the cement film thickness of two endodontic sealers in the apical region. Indian J Dent Res 2009; 20: 390.

27) Grossman L. Obturation of root canal. In: Grossman L, editor. Endodontic Practice. 10th ed. Philadelphia: Lea and Febiger; 1982. p. 297.

28) Saleh IM, Ruyter IE, Haapasalo M, Ørstavik D. The effects of dentine pretreatment on the adhesion of root-canal sealers. Int Endod J 2002; 35: 859-866.

29) Tay FR, Loushine RJ, Weller RN, Kimbrough WF, Pashley DH, Mak YF, Lai CN, Raina R, Williams MC. Ultrastructural evaluation of the apical seal in roots filled with a polycaprolactone-based root canal filling material. J Endod 2005; 31: 514-519.

30) Gharib SR, Tordik PA, Imamura GM, Baginski TA, Goodell GG. A confocal laser scanning microscope investigation of the epiphany obturation system. J Endod 2007; 33: 957-961.

31) Kara Tuncer A, Tuncer S. Effect of different final irrigation solutions on dentinal tubule penetration depth and percentage of root canal sealer. J Endod 2012; 38: 860-863.

32) Ferrari M, Mannocci F, Vichi A, Cagidiaco MC, Mjör IA. Bonding to root canal: structural characteristics of the substrate. Am J Dent 2000; 13: 255-260.

33) Violich D, Chandler N. The smear layer in endodontics - a review. Int Endod J 2010; 43: 2-15.

34) De-Deus G, Reis C, Di Giorgi K, Brandão MC, Audi C, Fidel RAS. Interfacial adaptation of the Epiphany self-adhesive sealer to root dentin. Oral Surg Oral Med Oral Pathol Oral Radiol Endod 2011; 111: 381-386.

35) Balguerie E, van der Sluis L, Vallaeys K, Gurgel-Georgelin M,
Diemer F. Sealer penetration and adaptation in the dentinal tubules: a scanning electron microscopic study. J Endod 2011; 37: 1576-1579.

36) Borges RP, Sousa-Neto MD, Versiani MA, Rached-Júnior FA, De-Deus G, Miranda CE, Pécora JD. Changes in the surface of four calcium silicate-containing endodontic materials and an epoxy resin-based sealer after a solubility test. Int Endod J 2012; 45: 419-428.

37) Dogan Buzoglu H, Calt S, Gümüsderelioglu M. Evaluation of the surface free energy on root canal dentine walls treated with chelating agents and $\mathrm{NaOCl}$. Int Endod J 2007; 40: 1824.

38) Shimada Y, Kondo Y, Inokoshi S, Tagami J, Antonucci JM. Demineralizing effect of dental cements on human dentin. Quintessence Int 1999; 30: 267-273.

39) Rahman Hashem AA, Ghoneim AG, Lutfy RA, Fouda MY. The effect of different irrigating solutions on bond strength of two root canal-filling systems. J Endod 2009; 35: 537-540.

40) Koch K, Brave D. A new day has dawned: the increased use of bioceramics in endodontics. Dentaltown 2009;10: 39-43.

41) Zhang H, Shen Y, Ruse ND, Haapasalo M. Antibacterial activity of endodontic sealers by modified direct contact test against Enterococcus faecalis. J Endod 2009; 35: 1051-1055.

42) Morgental RD, Vier-Pelisser FV, Oliveira SD, Antunes FC, Cogo DM, Kopper PM. Antibacterial activity of two MTAbased root canal sealers. Int Endod J 2011; 44: 1128-1133.

43) Sjögren U, Figdor D, Persson S, Sundqvist G. Influence of infection at the time of root filling on the outcome of endodontic treatment of teeth with apical periodontitis. Int Endod J 1997; 30: 297-306.

44) Barkhordar RA, Stark MM, Soelberg K. Evaluation of the apical sealing ability of apatite root canal sealer. Quintessence Int 1992; 23: 515-518.

45) Schäfer E, Olthoff G. Effect of three different sealers on the sealing ability of both thermafil obturators and cold laterally compacted Gutta-Percha. J Endod 2002; 28: 638-642.

46) Qualtrough AJ, Whitworth JM, Dummer PM. Preclinical endodontology: an international comparison. Int Endod J 1999; 32: 406-414.

47) Wu MK, Özok AR, Wesselink PR. Sealer distribution in root canals obturated by three techniques. Int Endod J 2000; 33: 340-345

48) Goldberg F, Artaza LP, De Silvio A. Effectiveness of different obturation techniques in the filling of simulated lateral canals. J Endod 2001; 27: 362-364. 